\title{
Estrogenic and anti-androgenic endocrine disrupting chemicals and their impact on the male reproductive system
}

\author{
Maria De Falco ${ }^{1,2 *}$, Maurizio Forte ${ }^{1,2}$ and Vincenza Laforgia ${ }^{1,2}$ \\ ${ }^{1}$ Section of Evolutionary and Comparative Biology, Department of Biology, University Federico II of Naples, Naples, Italy \\ ${ }^{2}$ National Institute of Biostructures and Biosystems, Rome, Italy
}

\section{Edited by:}

Eduardo Alves Almeida, São Paulo

State University, Brazil

\section{Reviewed by:}

Farzad Pakdel, University of Rennes, France

Daniele Dietrich Moura Costa,

Universidade Federal do Paraná,

Brazil

*Correspondence:

Maria De Falco, Section of

Evolutionary and Comparative

Biology, Department of Biology, Via

Mezzocannone, 880134 Naples,

Italy

e-mail:madefalco@unina.it
Endocrine disrupting chemicals (EDCs) are identified for their ability to perturb the homeostasis of endocrine system and hormonal balance. The male reproductive system is under close control of hormones and each change in their concentration and time of exposition and action can induce a deregulation of its physiology. In this review we summarize the most recent studies on two main categories of EDCs with different action: the estrogenic bisphenol $\mathrm{A}$ and alkylphenols and the anti-androgenic phthalates. This review describes the main effects of these substances on male reproductive system.

Keywords: endocrine disrupting chemicals (EDCs), bisphenol A (BPA), nonylphenol (NP), phthalates, Testicular Dysgenesis Syndrome (TDS)

\section{INTRODUCTION}

Environmental compounds belonging to endocrine disrupting chemicals (EDCs) are an heterogeneous group of ubiquitous synthetic or natural substances defined according to three criteria: endocrine activity, adversity of effects and a possible correlation cause-effect (Alexander et al., 2013; Svechnikov et al., 2014). EDCs can be used in industry for many different applications such as lubricants and solvents (polychlorinated biphenyls $[\mathrm{PCB}]$, polybrominated diphenyl ethers $[\mathrm{PBDE}]$ and dioxins) (Shi et al., 2007; Darnerud, 2008; Pocar et al., 2012), plastics (bisphenol A [BPA], and bisphenol S [BPS]) (Rubin, 2011; Vinas and Watson, 2013), plasticisers (phthalates) (Hauser and Calafat, 2005), pesticides and herbicides (atrazine, cypermethrin, dichlorodiphenyltrichloroehane [DDT], dieldrin, methoxychlor [MXC], and vinclozolin [VCZ]) (Kavlock and Cummings, 2005; Tiemann, 2008; Hayes et al., 2011; Wang et al., 2011), and organic compounds (diethylstilbestrol [DES], ethyl estradiol [EE]) (Herbst et al., 1971; Hogan et al., 2010). It has been shown that the primary source of human and animal exposure is the diet since the population is exposed to EDCs mainly through ingestion of contaminated food or water. However, a further exposure can also happen through inhalation of contaminated air and dust or through skin contact (Jeng, 2014). Moreover, recently it has been shown that human exposition can occur through medical consumables and devices such as catheters, breathing and respiratory equipment and blood bags containing different mixtures of EDCs (Ponzo and Carbone, 2013). EDCs can affect multiple endocrine pathways, hormonal and homeostatic systems, but they particularly influence and perturb the steroidogenesis and the reproduction since most of the effects are exerted through disturbance of estrogen or androgen-mediated processes (del Mazo et al., 2013; Knez, 2013; Marques-Pinto and Carvalho, 2013; Zhang et al., 2014). Many EDCs are xeno-estrogens able to bind the estrogen receptor (ER) with an affinity 1000-fold lower than that of estrogen (Lee et al., 2013). Specifically, EDCs can affect cells and biological systems through different mechanisms, by agonistic or antagonistic interaction with hormone receptors, altering the production of endogenous hormones (the synthesis, transport, and metabolism) and even inducing intersex (Lange et al., 2009; Zhao and Hu, 2012; Cao et al., 2013; Ji et al., 2013; Svechnikov et al., 2014; Yu et al., 2014). Other less well known mechanisms of action of EDCs include alterations of genetic systems (Edwards and Myers, 2007; del Mazo et al., 2013), direct effects on genes (Moral et al., 2008) and the EDC epigenetic impact (Anway and Skinner, 2008). These effects are particularly troubling since alterations in genetic programming during early stages of development may have profound effects years later and may also lead to transgenerational inheritance of disease (Schug et al., 2011; Skinner, 2011). Environmental substances are considered accountable for the increasing incidence of human reproductive diseases and the consequent decline in reproductive function worldwide (Balabanic et al., 2011; Woodruff, 2011; Marques-Pinto and Carvalho, 2013). It has been demonstrated that over 50 years, the global average sperm count dropped by half, from 113 to 66 million/ml (about $1 \%$ at year), whereas sperm morphology/motility abnormalities significantly increased (Carlsen et al., 1992; Marques-Pinto and Carvalho, 2013). The reproductive male function in humans is regulated by a number of hormones and paracrine factors (Svechnikov et al., 2014). Hence, in order to study disturbances, it is important to consider 
first the physiological mechanisms of a healthy sperm production (Knez, 2013). The development of the male reproductive system requires the activation of specific pathway by hormones, such as androgens and anti-Müllerian hormone (AMH). Testis cell development is dependent on the local action of hormones, such how most aspects of masculinization depend on normal testicular hormone production (Knez, 2013). Normal testicular development in fetus depends on the differentiation and development of Leydig and Sertoli cells, which are necessary for the subsequent development of reproductive tract (Magre and Jost, 1991; Lejeune et al., 1998; Yu et al., 2014). Fetal Leydig cells (FLCs) are a major source of androgens in the prenatally developing male (Svechnikov et al., 2014). The Sertoli cells, considered as nurse cells for spermatogenesis, are the first cells that can be identified in the early fetal testis and are crucial for the seminiferous cord formation and Leydig cell functionality (Sharpe et al., 2003; Svechnikov et al., 2014). Moreover, the Sertoli cells secrete $\mathrm{AMH}$, which induces the regression of the Müllerian duct (Wilson, 1978; Svechnikov et al., 2014). Specific gene expression together with autocrine, paracrine and endocrine regulations allow the continuous production of sperm in adult life (Brennan and Capel, 2004; Park and Jameson, 2005; del Mazo et al., 2013). The rapid increase in reproductive disorders suggests that environmental or lifestyle factors, rather than genetic defects are the most likely causes (Svechnikov et al., 2014). Specifically, previous researches on male reproduction have mainly focused on changes at the level of serum testosterone (Zhang et al., 2014). This androgen, together with dihydrotestosterone (DHT) that is produced locally from testosterone by 5 - $\alpha$-reductase, play a pivotal role in the masculinization of external genitalia and prostate of the male fetus, driving the process of "making a male" during a specific period of fetal development named "masculinization programming window" (Fisher, 2004; Welsh et al., 2008; Scott et al., 2009; Knez, 2013; Svechnikov et al., 2014). In humans this window extends from 6.5 to 14 gestational week (N'Tumba-Byn et al., 2012); whereas, testosterone reaches its maximal values between 11 and 18 weeks of gestation and stimulates differentiation of the Wolffian duct into epididymis, vas deferens and seminal vesicles and prostate (Svechnikov et al., 2014). On the contrary, differentiation of prostate and external genitalia (penis, scrotum, and perineum) is mediated by DHT (Svechnikov et al., 2014). It seems likely that the abnormal development of testes in fetal and neonatal life can have long-term consequences for sperm production (Sharpe, 2001; Knez, 2013). Although androgens are the most important hormones in the normal development of the male reproductive system (Knez, 2013), more recently, it has been suggested a central role for estrogen in testicular function, due to the presence of large quantities of estrogen in the rete testis fluid and spermatic veins of numerous mammals (Hess, 2003; Zhang et al., 2014). So, the balance between androgens and estrogens may be important in maintaining normal spermatogenesis (Zhang et al., 2010, 2014; Williams et al., 2011). Therefore, the exposition to xenoestrogens and anti-androgens during fetal and neonatal development has been associated with a series of male reproductive disturbances, such as cryptorchidism, hypospadias, impaired fertility (especially due to poor semen quality), and an elevated incidence of testicular cancer (McLachlan et al., 1975;
Gill et al., 1979; Jensen et al., 1995; Zhang et al., 2014). These four clinical and etiologically related symptoms have been assembled in the Testicular Dysgenesis Syndrome (TDS) (del Mazo et al., 2013) and they probably arise from intrauterine disruption of proper testicular development and function (Vega et al., 2012) under EDCs exposure (Massart and Saggese, 2009; MarquesPinto and Carvalho, 2013). Thus, TDS entries in the concept of DOHaD (Developmental Origins of Health and Disease) (Schug et al., 2011). The perinatal period is one of the sensitive windows of development wherein minor hormonal perturbations may have a long lasting impact on fertility (Saunders et al., 1997; Si et al., 2015). So, endocrine disruption in developing organism may determine the propensity of individual to develop a disease or dysfunction later in life (Barker, 2004; Diamanti-Kandarakis et al., 2009). In fact, it is well accepted that a lag between the time of exposure to EDCs and the manifestation of a disorder can occur (Diamanti-Kandarakis et al., 2009; Isling et al., 2014). Furthermore, many EDCs influence the anogenital distance, a parameter used as biomarker of reproductive effects.

Many studies based on epidemiological data show links between environmental factors and hypospadias and cryptorchidism. Hypospadias is a condition that affects about $0.4 \%$ of males in which the opening of the urethra is on the ventral side of the penis rather than at the tip of the glans penis (Marques-Pinto and Carvalho, 2013; Jeng, 2014). Hypospadias may arise during the first trimester of in utero life and it is classified as mild (first degree) to severe (third degree) (Jeng, 2014). Specifically, it has been demonstrated that exposure of male fetuses in utero to different EDCs such as vinclozolin, PCBs, phthalates and dioxins (Kristensen et al., 1997; Baskin et al., 2001; Gray et al., 2001; Fisher et al., 2003) or residence location in the vicinity of hazardous waste disposal sites induce hypospadias in boys of the resident families (Dolk et al., 1998; Elliott et al., 2001; Svechnikov et al., 2014). An example is Seveso industrial accident that induced a high incidence of hypospadias in male children of parents exposed to dioxin (Mastroiacovo et al., 1988). Father or mother (Vrijiheid et al., 2003) occupational exposures such as farmer handling herbicides (Garry et al., 2002), firemen (Schnitzer et al., 1995) or vehicle mechanics (Irgens et al., 2000) has been shown to highly contribute to incidence of this malformation (Svechnikov et al., 2014). Although cryptorchidism is often considered a mild malformation, it represent the best characterized risk factor for infertility and testicular cancer in adulthood (Svechnikov et al., 2014). It is defined as the failure of one or both testicles to descend into the scrotal sac which likely occurs by 6 months of age and it is the common congenital abnormality in male children, affecting 2-4\% of full-term males (Boisen et al., 2004; Marques-Pinto and Carvalho, 2013). Multiple studies suggest the interaction between EDCs in etiology of this disorder. Specifically, EDCs with antiandrogenic (Stoker et al., 2005) or estrogenic effects such as organohalogen pollutants, phthalates and compounds like PBDEs (Main et al., 2007) or DES (Stillman, 1982) have the potential of disturbing cellular events that control the testicular descent in humans (Svechnikov et al., 2014). Moreover, EDCs such as dibromochloropropane, ethylene dibromide, chlordecone, organophosphate may directly affect spermatogenesis by damaging the spermatogonia, destroying Sertoli 
cells or changing the morphology or motility of spermatozoa (Sever et al., 1997; Padungtod et al., 2000; Bretveld et al., 2007; Svechnikov et al., 2014). The late detrimental effects are semen quality, sperm count, motility and morphology (Svechnikov et al., 2014).

This review describes the effects of two main categories of EDCs: bisphenol and alkylphenols and phthalates that show opposite actions (xenoestreogens and anti-androgens) on the male reproductive system.

\section{BPA AND ALKYPHENOLS BISPENOL A}

BPA (4,4-dihydroxy-2,2-diphenylpropane) is a xenoestrogenic endocrine-disrupting chemical used in the manufacture of polycarbonate plastics and epoxy resins, such as food and drink containers, plastic water bottles, baby bottles, dental sealants and a variety of household products (compact disks, consumer electronics) (Knez, 2013; Liu et al., 2013). It is widespread in the environment and every year 2.2-4.7 million tons of BPA are released into the environment, of which around 1.2 million tons are produced in EU and the amounts are rising by about 6-8\% yearly (Fernandez, 2010; Vandenberg et al., 2010; Huang et al., 2012; Knez, 2013; Liu et al., 2013). Human beings are mainly exposed to BPA via dietary ingestion of leachings from the inner lining of cans and microwave containers during heating of food materials of through beverages in polycarbonate bottles due to repeated usage or contact with acid/alkaline (Biles et al., 1997; Jeng, 2014). It has been valued that the human body is exposed to concentrations of $10 \mu \mathrm{g} /$ day of BPA and it can be detected in several human body samples, such as serum, urine, amniotic fluid of pregnant women, breast milk and even in semen (Inoue et al., 2002; Calafat et al., 2005; Carlsen et al., 2005; EC-SCF, 2006; Phillips and Tanphaichitr, 2008; Lagos-Cabré and Moreno, 2012). BPA quantification in amniotic fluid and in umbilical cord reported a mean level around $1 \mathrm{ng} / \mathrm{ml}$ (Fenichel et al., 2012; N'Tumba-Byn et al., 2012). It has been estimated that urinary BPA is detected in $>90 \%$ of Americans (Lang et al., 2008; Liu et al., 2013). Furthermore, it has been proposed that BPA might accumulate particularly in early fetuses because of lower metabolic clearance of conjugation at this development stage (Ikezuki et al., 2002; N’Tumba-Byn et al., 2012). Several studies have shown that increased urine BPA levels may be associated with decreased sperm concentrations ( $\mathrm{Li}$ et al., 2011), decreased semen quality and increased single strands breaks of sperm DNA damage (Meeker et al., 2010; Liu et al., 2013). Moreover, it has been demonstrated that in males, BPA and estrogen perinatal exposure affects fertility and has the potential to induce blood-testis barrier restructuring (Li et al., 2009), disruptions in Sertoli cell junctional proteins (Salian et al., 2009), germ cell apoptosis, and disruption of spermatogenesis (Liu et al., 2013). All these targets by BPA and estrogens highlight ability of these compounds to perturb normal cell morphology and homeostasis inducing cell deregulation. All these cell alterations may lead to infertility in adulthood through germ loss via immunological activity (Toyama and Yuasa, 2004; Salian et al., 2009; Marques-Pinto and Carvalho, 2013). Recent findings suggest that human fetal steroidogenesis is highly sensitive to low environmentally relevant doses of BPA through the involvement of ER receptor and/or membrane-bound GPR30 in the regulation of the hormonal function of human FLCs (N’Tumba-Byn et al., 2012; Svechnikov et al., 2014). In humans, it has been demonstrated a positive correlation between BPA and total/free testosterone values in men and that BPA is related to lower FSH concentrations (Hanaoka et al., 2002; Knez, 2013). Moreover, a significant inverse association has been detected among urinary BPA concentrations free androgen index (FAI) levels and the FAI/LH ratio, as well as a positive association between BPA and sex hormone-binding globulin (SHBG) suggesting that BPA concentrations may be linked to subtle variations in sex hormones in fertile men (Lagos-Cabré and Moreno, 2012). Great attention should be done to animal model used in toxicological and endocrinological studies of EDC effects, since marked differences can be recorded. For example, as indicated by Richter et al. (2007) the outbred Sprague-Dawley CD rat from Charles River Laboratories has very low sensitivity to exogenous estrogens in contrast to male and female CD-1 (ICR) mice that are highly sensitive to EDC exposure (Richter et al., 2007). It has been demonstrated that prenatal, perinatal and adult exposure to BPA causes developmental genitourinary anomalies, decreased epididymal weight, daily sperm production or increased prostate weight in laboratory rodents. Several studies have confirmed that BPA is able to induce detrimental effect at doses lower than $50 \mathrm{mg} / \mathrm{kg} / \mathrm{day}$, which is currently accepted in USA as the lowest dose used to estimate the lowest observed adverse effect level (LOAEL) and so to calculate the acceptable daily intake in humans (Nagel et al., 1997; vom Saal et al., 1998; Williams et al., 2001; Richter et al., 2007; Salian et al., 2009; Knez, 2013). The dangerousness of EDCs and also of BPA is that these substances are able to induce different and multiple effects on several target cells and organs also in a non-linear manner and at not predictive concentrations. So, researches on EDCs would necessarily use appropriate positive and negative controls. For example, in a study performed on male mice with $40 \mu \mathrm{g} / \mathrm{kg}$ for 7 weeks, it has been observed a marked decrease in the number of spermatozoa, semen quality and abnormal spermatogenesis (Lee et al., 2013). In neonatal male rats treated for 5 days with BPA was observed a low sperm count and motility in adulthood, accompanied by a low mating rate and sloughing of germ cells, demonstrating a long-term effects of this substance (Salian et al., 2009; Lagos-Cabré and Moreno, 2012). A reduction on Leydig cell numbers, multinucleated germ cells (MNGs) and T plasma levels have been observed in pubertal mice orally receiving 160 $960 \mathrm{mg} / \mathrm{kg}$ of BPA for 13 days (Takao et al., 2003; Li et al., 2009; Lagos-Cabré and Moreno, 2012). These results highlight the BPA negative power to influence and perturb male reproductive system in different stages. It has been demonstrated that exposure to environmentally relevant BPA levels has adverse effects on testicular function by decreasing pituitary LH secretion and reducing Leydig cell steroidogenesis (Akingbemi et al., 2004; Svechnikov et al., 2010). Through in vitro studies, it has been shown that BPA act directly in Leydig cells decreasing testosterone production (Akingbemi et al., 2004; Svechnikov et al., 2010). An other target inside the male reproductive system is the prostate which development and differentiation as well as the maintenance of adult homeostasis is regulated by both androgens and estrogens (Arase et al., 2011). Fetal exposure to low-dose BPA $(10 \mu \mathrm{g} / \mathrm{kg} /$ day $)$ 
increased cell proliferation of urogenital sinus epithelium (UGE) in the primary prostatic ducts of CD1 mice (Timms et al., 2005; Arase et al., 2011). This effect was confirmed also by in vivo study where low-dose BPA $(20 \mu \mathrm{g} / \mathrm{kg} /$ day $)$ increased the number of basal epithelial cells in the adult prostate of BALB7c mice and induced permanent cytokeratin 10 expression in such cells similar to the effects of DES (Ogura et al., 2007; Arase et al., 2011). Several studies have shown that prenatal exposure to BPA causes hyperplasia of prostate in male rats resulting in greater risk of prostate cancer (Ho et al., 2006; Jeng, 2014). Moreover, neonatal exposure of male rats to low-dose BPA $(10 \mu \mathrm{g} / \mathrm{kg} /$ day $)$ elicited critical molecular changes during prostate development and also increased prostatic gland susceptibility to precancerous neoplastic lesions and hormonal carcinogenesis (Ho et al., 2006; Arase et al., 2011). Furthermore, it has been demonstrated that also in the prostate such as in other reproductive organs BPA was able to negatively affect the in situ steroidogenesis inducing an increase of aromatase activity (Arase et al., 2011).

\section{ALKYLPHENOLS}

Alkylphenols are used as industrial intermediaries and surfactants in the production of non-ionic detergents, latex paint, adhesives and plastics as the polystyrene, polymer stabilizers to package food, common consumer products such as detergents, disinfectants, surface cleaners, cosmetic products, herbicides and pesticides, and also antioxidant agents and lubricant additives (Soto et al., 1991; Inoue et al., 2001; Shaw and McCully, 2002). The annual production of alkylphenols has been estimated to be 154,000 tons in the USA and 75,000 tons in the EU (Soares et al., 2008; Knez, 2013). The most important members of this group are nonylphenol ethoxylate (NPE) and octylphenol ethoxilate (OPE) (Tubau et al., 2010; Knez, 2013). These substances undergo metabolic breakdown in the environment and lose ethylene oxide side chains to become alkylphenols (4-n-octylphenol and 4-nnonylphenol). Unlike most of the exogenous chemicals, which usually become less toxic with biodegradation, alkylphenols actually increase their toxicity during this process (Knez, 2013). The main exposition source for humans is the food and all these substances or their metabolites have been detected in human urine, serum, amniotic fluid of pregnant women, in breast milk and even in semen (Guenther et al., 2002; Calafat et al., 2005; Main et al., 2006; Huang et al., 2009; Knez, 2013). It has been valued that the human body is daily exposed to about $7.5 \mu \mathrm{g} /$ day of nonylphenol (NP) (Lagos-Cabré and Moreno, 2012). In rodent models exposed to NP or OP, it has been shown a testicular damage with a decrease in the testicular size and weight, in the epididymis and sperm production, an increase of the intertubular space and low seminal quality (Jager et al., 1999; Lee et al., 1999; Chitra et al., 2002; Herath et al., 2004; Lagos-Cabré and Moreno, 2012; Knez, 2013; Ponzo and Carbone, 2013). Moreover, NP exposure neonatally, in early stages of sexual maturation and in adulthood rat, led to a histological disorganization of the epithelium seminiferus of testis (Ponzo and Carbone, 2013), a reduction in testis, epididymis and seminal vesicle size other than an increase of cryptorchidism up to a 60\% (Lee, 1998; Nagao et al., 2001; Fan et al., 2010; Ponzo and Carbone, 2013). All these results clearly demonstrate that alkylphenols and particularly NP are able to influence the correct development and physiology of male reproductive system, specifically target testis and epididymis. These organs are particularly important for the quality of spermatozoa and reproductive fitness. Moreover, NP administration to pregnant rats during gestation, lactancy and 10 weeks after weaning (corresponding to a complete lifespan exposed to NP) have been shown to decrease epithelial thickness, probably due to Sertoli cells shrinking and an increase in germ cell apoptosis (De Jager et al., 1999; McClusky et al., 2007; Lagos-Cabré and Moreno, 2012). Moreover, NP administered to rats during adulthood and also from fetal development until adulthood decreased testosterone levels (Laurenzana et al., 2002; Gong and Han, 2006; Ponzo and Carbone, 2013). So, NP is able to have various cell targets and to activate and deregulate different cell pathways involved in testis physiology and testosterone production.

\section{PHTHALATES}

Phthalates are industrial chemicals with very different applications and toxicological properties. Specifically, they are used as plasticizers to add softness, flexibility, durability, transparency, and longevity to a variety of consumer, industrial, and medical products (Johnson et al., 2012; Martinez-Arguelles et al., 2013). They are broadly used in the manufacture of plastics, solvents, sealants, paints, varnishes, detergents, cosmetics, and personal care products, toys, household products, as well as in the food processing, medical and pharmaceutical industries (Jurewicz and Hanke, 2011; Wittassek et al., 2011; Johnson et al., 2012; Moody et al., 2013). They are classified in two distinct groups based on molecular weight: (a) high molecular weight compound (di-2-ethylexyl phthalate-DEHP), primarily used as plasticizers in the manufacture of flexible vinyl plastic present in consumer products, flooring and wall covering and medical devices [Agency for Toxic Substances and Disease Registry (ATSDR), 2002; Jeng, 2014]; (b) low molecular weight compounds (diethyl phthalate, dibutyl phthalate, DBP), used in personal care products such as solvents for perfumes and fixatives for hair spray (Chen et al., 2011), as solvents and plasticizers for cellulose acetate (Jeng, 2014). Thus, they can be found in food containers, adhesives, perfumes and eye shadow (Knez, 2013). Moreover, many importance have been done to phthalate metabolites such as three di-(2-ethylexyl) phthalates, mono-(2ethylexyl) phthalate (MEHP), mono-(2-ethyl-5-hydroxyhexyl) phthalate (MEHHP), and mono-(2-ethyl-5-oxohexyl) phthalate (MEOHP) (Jeng, 2014). Among phthalates, DEHP is the most widely used to convey flexibility and transparency to numerous plastics made of polyvinyl choride (PVC) (Latini et al., 2003; Ponzo and Carbone, 2013). Since phthalates are not covalently bound to the polymer, they can leach from plastics into foods, beverages and body fluids (Lovekamp and Davis, 2001; Moore et al., 2001; Ponzo and Carbone, 2013) with product age, use, and ultraviolet light exposure, making them available for biological exposure (Thomas and Thomas, 1984; Johnson et al., 2012). In fact, human exposure occurs by ingestion, absorption, inhalation and dermal exposure, and different studies confirmed phthalate metabolite presence in human urine, breast milk samples and some serum (Hines et al., 2009; Frederiksen et al., 2011; Göen et al., 2011; Wittassek et al., 2011; Moody et al., 2013). In humans, 
maternal exposure to phthalates (Adibi et al., 2003, 2009; Latini et al., 2003; Swan et al., 2005; Martinez-Arguelles et al., 2013) provides the first source of fetal exposure, through amniotic fluid (Silva et al., 2004), umbilical cord blood (Latini et al., 2006), and other bodily fluids (Silva et al., 2005; Martinez-Arguelles et al., 2013). It is reckoned that around 6 million tons of phthalates are produced worldwide every year (Rudel and Perovich, 2009; Knez, 2013). Typical daily phthalate intake in humans is estimated at 1.7-52.1 $\mu \mathrm{g} / \mathrm{kg} /$ day (Doull et al., 1999; Koch et al., 2003; McKee et al., 2004; Frederiksen et al., 2011; Martinez-Arguelles et al., 2013), whereas children exposure is 2- to 4-fold higher than adults (Koch et al., 2005; Moody et al., 2013). Moreover, individuals, especially children with long-term medical conditions have much greater exposure than general population since the use of phthalates in medications and medical devices (Moody et al., 2013), with an estimated exposure of $20 \mathrm{mg}$ phthalate per day (Plonait et al., 1993; Green et al., 2005; Su et al., 2012; Moody et al., 2013). Phthalates are considered to be one of the major groups of antiandrogenic substances (Grady and Sathyanarayana, 2012; Knez, 2013). Several toxicological studies have demonstrated a link between phthalate exposure and disorders of male reproductive development, such as hypospadias, cryptorchidism, smaller testes and penis size, alterations of the vas deferens and epididymis, reduction of the anogenital distance and the presence of MNGs (Cortes et al., 2003; Fisher et al., 2003; Foster, 2006; Knez, 2013), and adult pathologies such as Leydig cell aggregation (HoeiHansen et al., 2003; Holm et al., 2003; Nistal et al., 2006), Sertoli cell-only tubules, poor spermatogenesis (Nistal et al., 2006), testicular germ cell tumors and reduced semen quality (Moody et al., 2013; Jeng, 2014). Moreover, in two independent studies, phthalate levels in urine from pregnant women have shown significant inverse correlations with AGD of their male offspring (Swan et al., 2005; Suzuki et al., 2011; Johnson et al., 2012). Furthermore, exploring the neonatal maternofetal unit, it has been observed an inverse correlation between phthalate levels in human breast milk and serum-free testosterone in their suckling males and a positive correlation between breast milk phthalate levels and serum luteinizing hormone/testosterone ratios (Main et al., 2006; Johnson et al., 2012). Recently, a study conducted on 463 men found significant dose-response associations between mono-butyl phthalate (MBP) concentration and low sperm concentration and low motility (Hauser et al., 2006; Jeng, 2014). An other study on 344 men who had normal semen concentration have shown that several urinary phthalate metabolites (5-OH-MEHP, MEHP, mono-isobutyl phthalate MiBP) were significantly associated with a decrease in sperm motility (Jurewicz et al., 2013; Jeng, 2014). By the use of human man models, it is possible speculate that in our species phthalates are able to influence hormonal homeostasis and balance in male reproductive system inducing a deregulation of normal sperm activity. Moreover, using animal models, it has been shown that DEHP results in testicular toxicity and impaired steroidogenesis and can cause birth defects (Srivastava et al., 1990; Park et al., 2002; Ponzo and Carbone, 2013; Jeng, 2014) producing a phenotype termed the "phthalate syndrome" that comprises non-descent of testis, malformations of external genitalia, poor semen quality, and malformations of other sex organs (Foster, 2006; Johnson et al., 2012). It has been demonstrated that exists a critical in utero exposure window for reproductive malformations. The critical phthalate exposure window for reproductive tract lesion development encompasses approximately GD16-GD18 (Ema et al., 2000; Carruthers and Foster, 2005; Johnson et al., 2012). However, phthalates inhibit fetal testis testosterone production during the entire fetal period when the testis is highly steroidogenic (Parks et al., 2000; Thompson et al., 2004, 2005; Plummer et al., 2007; Scott et al., 2008; Hannas et al., 2011; Johnson et al., 2012). In utero phthalate exposure alters seminiferous cord development with delayed maturation, focal, dysgenetic cords with intracordal Leydig cells and, more generally, cords with larger diameters harboring a large number of MNGs (Boekelheide et al., 2009; Johnson et al., 2012). The primary target cells of phthalate exposure seem to be mesenchymal and peritubular myoid cells which functional changes lead to functional perturbations of Leydig, Sertoli, and germ cells (Johnson et al., 2012). Sertoli cells are the next apparent target for phthalate-induced effects on the seminiferous cords, manifesting immaturity and alterations in their apical processes, cytoskeleton, and interactions with germ cells (Fisher et al., 2003; Kleymenova et al., 2005; Johnson et al., 2012). Phthalate exposure reduces the percentage of proliferating rat Sertoli cells by about 40\% (Hutchison et al., 2008; Scott et al., 2008; Johnson et al., 2012). Because Sertoli cell proliferation depend on Leydig cell testosterone output (Scott et al., 2007), the decrease of Sertoli cell proliferation is downstream of Leydig cell steroidogenic inhibition (Johnson et al., 2012). For these reason the critical phthalate exposure window for Sertoli cell proliferation effects is between GD19 and GD21 (Scott et al., 2008; Johnson et al., 2012). These results performed on animal models highlight some of possible cell targets of phthalates that in turn can explain their effects on human man fertility. It has been observed that DEHP administered by gavage during gestation and lactation at high dose produced nipple retention, reduced anogenital distance, reduced testosterone formation by the fetal testis due to reduced expression of enzymes and proteins involved in steroidogenesis (Culty et al., 2008; Martinez-Arguelles et al., 2013) and caused histological changes in the testis, indicating its anti-androgen effects (Andrade et al., 2006; Ponzo and Carbone, 2013). Moreover, adult male offspring exposed in utero to increasing doses of DEHP showed decreased testosterone levels in presence of near normal Leydig cell numbers, so suggesting that DEHP is able to target the stem cells of the adult-type Leydig cells (Culty et al., 2008; Martinez-Arguelles et al., 2009, 2011, 2013). Low dose of DEHP administered at pre- and post-natal stage or to prepubertal and adult rat was able to induce alteration of Leydig cell development (Akingbemi et al., 2001; Ponzo and Carbone, 2013). High dose of DEHP also induced testicular malformations in the male rat offspring (Parks et al., 2000). DEHP has been shown to disrupt the androgen-regulated development of the male reproductive tract reducing absolute and relative weights of ventral prostate and seminal vesicle, altering spermatogenic processes (Dalsenter et al., 2006; Ponzo and Carbone, 2013). Moreover, perinatal exposure to DEHP induced a significant incidence of reproductive malformations in male pups such as reduced anogenital distance and testis weights (Gray et al., 2000; Ponzo and Carbone, 2013). DEHP chronic postnatal exposure 
strongly affected Leydig cell hormonal functions by a decrease of testosterone biosynthesis and an increase of LH and estradiol (Akingbemi et al., 2004; Ponzo and Carbone, 2013). In rats, DEHP is rapidly hydrolyzed in the gut to MEHP that is ten-times more potent than DEHP in vitro (Huber et al., 1996; Gupta et al., 2010; Martinez-Arguelles et al., 2013), which pass into breast milk and cross the placental barrier (Latini et al., 2003; Stroheker et al., 2005; Ponzo and Carbone, 2013). Among phthalates, DBP is a main product of phthalate esters (PAEs) and seem that the general population is exposed to disproportionately higher amounts of DBP relative to other phthalates (Blount et al., 2000; Chen et al., 2011). It has been demonstrated that DBP has anti-androgenic activity and particularly affects the neonatal-prepubertal mouse testis (Moody et al., 2013). Prepuberty is a critical time during which the foundations of adult fertility are being established (Moody et al., 2013). It has been shown that DBP increased AMH that in turn affects development and maturation of adult Leydig cells, alters their eventual number or impairs their steroidogenic capacity (Moody et al., 2013). On the contrary, MEHP increased apoptosis of germ cells and reduced expression of AMH mRNA (Lambrot et al., 2009). Several studies have shown that DBP produced marked changes in the growth and development of the male reproductive organs, including absent or deformed epididymidis, cryptorchidism, hypospadias, reduced fertility and Leydig cell adenomas (Mylchreest et al., 2000, 2002; Mahood et al., 2007; Chen et al., 2011). The hyperplasia of Leydig cells induced by DBP could be a compensatory mechanism designed to increase testicular steroidogenesis in response to levels of testosterone that are insufficient to promote normal differentiation of the male reproductive tract (Mylchreest et al., 2002; Svechnikov et al., 2010). In a study performed on adult rats, oral exposure to DBP at $250 \mathrm{mg} / \mathrm{kg}$ induced a decrease of the sperm count, an increase of the abnormal sperm percentage, an increase of synthesis of testosterone (Chen et al., 2011).

Like many EDCs, also phthalate and their metabolites have been suggested to interfere with normal steroidogenesis, suppressing the expression of steroidogenic enzymes (Moody et al., 2013), disrupting the regulation of cholesterol and lipid homeostasis or insulin signaling (Barlow et al., 2003; Liu et al., 2005; Knez, 2013). Phthalate exposure reduces testis cholesterol and cholesterol-containing lipid droplets in rat FLCs (Barlow et al., 2003; Lehmann et al., 2004; Johnson et al., 2011, 2012). Specifically, the immediate event precipitating Leydig cell testosterone attenuation appears to be the reduced expression of mRNA and protein within the cholesterol trafficking/biosynthesis and steroidogenic enzymatic pathways (Johnson et al., 2012). Urinary phthalate metabolite levels were negatively associated with testosterone levels (Pan et al., 2006; Mendiola et al., 2011), folliclestimulating hormone (FSH) (Duty et al., 2005), and luteinizing hormone (LH) (Jönsson et al., 2005; Jeng, 2014). Particularly, PAEs and DEHP were observed to exert a direct effect on Leydig or Sertoli cell structure and function (Jones et al., 1993; Sharpe, 2001; Jeng, 2014) specifically acting on testosterone synthesis inhibition in Leydig cells (Desdoits-Lethimonier et al., 2012). It has been demonstrated that some phthalates disrupt the pattern of gene expression that regulate cholesterol and lipid homeostasis or insulin signaling inducing a decrease of testosterone synthesis (Barlow et al., 2003; Jeng, 2014). Using the Leydig cell tumor MA-10 cell line, it has been demonstrated that MEHP increases lipid droplets and decreases progesterone production (Dees et al., 2001), suggesting that cholesterol is not transported into the mitochondria for steroid biosynthesis, but rather accumulated in lipid droplets (Martinez-Arguelles et al., 2013). Similar results have been observed in vivo using Wistar rats with a decrease of testosterone levels and increase of testicular cholesterol content (Botelho et al., 2009; Martinez-Arguelles et al., 2013). Short-term (12-h) in vitro incubation of spermatozoa with the highest concentrations of phthalates detected in human semen samples through environmental exposure resulted in decreased sperm motility, whilst prolonged incubation (96 h) resulted in sperm citotoxicity (Pant et al., 2011). Studies on human fetal testis explants demonstrated a role of phthalates on human steroidogenesis with inhibition of testosterone production (Desdoits-Lethimonier et al., 2012; Knez, 2013). Moreover, Wang et al. $(2006,2007)$ demonstrated that in vitro a low dose (1000 nmol/L), MBP, an active metabolite of DBP, exhibited a stimulating effect on steroidogenesis, while exhibiting an inhibiting effect at a higher dose $(800 \mu \mathrm{mol} / \mathrm{L})$ suggesting an inverted $\mathrm{U}$ dose-response curve common to several EDCs (Chen et al., 2011). Moreover, phthalate has been shown induce sperm DNA damage. Specifically, in a US study, an association between increased sperm DNA damage and MEP and MEHP was found (Duty et al., 2003; Hauser et al., 2007; Jurewicz et al., 2013; Jeng, 2014). Human phthalate exposure levels in the general population are low as compared with the dose levels required to elicit reproductive toxicity in the rat. Although this appears to suggest a negligible human male reproductive system risk, phthalates are only one component of a mixture of chemicals to which humans are exposed. Since humans are continuously exposed to multiple combinations of compounds with anti-androgenic and estrogenic effects, it is important to assess the joint action exhibited by mixtures of chemicals that disrupt a common system or target tissue instead of chemicals sharing a narrowly defined mechanism of toxicity (Kortenkamp et al., 2007; Kortenkamp and Faust, 2010; Nordkap et al., 2012). When combined with other EDC in rats, it is clear that phthalates contribute to reproductive toxicity below the no-observed-adverse-effect level of individual phthalate congener exposures (Committee on the Health Risks of Phthalates, 2008; Johnson et al., 2012).

\section{CONCLUDING REMARKS}

Studies of the last decade strongly support that male reproductive health has been deteriorating (Diamanti-Kandarakis et al., 2009; Soto and Sonnenschein, 2010; Svechnikov et al., 2010; Si et al., 2015). Specifically, reproductive effects after developmental exposure to mixtures of environmental EDCs have been observed both shortly after birth, in puberty, and in young adulthood (Hass et al., 2007, 2012; Christiansen et al., 2012; Jacobsen et al., 2012; Isling et al., 2014). The complexity of the mechanisms involved in EDC actions means that their health effects can be the result of the action through multiple pathways, potentially leading to greaterthan-additive-effects (Kortenkamp, 2007; Knez, 2013). Such interactions among different EDCs could even allow substances that would not produce any effects by themselves to produce 
significant effects at concentrations present in the environment (Kortenkamp, 2007; Christiansen et al., 2012; Knez, 2013).

\section{REFERENCES}

Adibi, J. J., Hauser, R., Williams, P. L., Whyatt, R. M., Calafat, A. M., Nelson, H., et al. (2009). Maternal urinary metabolites of di-(2-ethylhexyl) phthalatein relation to the timing of labor in a US multicenter pregnancy cohort study. Am. J. Epidemiol. 169, 1015-1024. doi: 10.1093/aje/kwp001

Adibi, J. J., Perera, F. P., Jedrychowski, W., Camann, D. E., Barr, D., Jacek, R., et al. (2003). Prenatal exposures to phthalates among women in New York City and Krakow, Poland. Environ. Health Perspect. 111, 1719-1722. doi: 10.1289/ehp.6235

Agency for Toxic Substances and Disease Registry (ATSDR). (2002). Toxicological Profile for Di(2-Ethylnexyl) Phthalate (DEHP). Washington, DC: U.S. Department of Health and Human Services.

Akingbemi, B. T., Youker, R. T., Sottas, C. M., Ge, R., Katz, E., Klinefelter, G. R., et al. (2001). Modulation of rat Leydig cell steroidogenic function by di(2-ethylhexyl)phthalate. Biol. Reprod. 65, 1252-1259. doi: 10.1095/biolreprod65.4.1252

Akingbemi, B. T., Ge, R., Klinefelter, G. R., Zirkin, B. R., and Hardy, M. P. (2004). Phthalate-induced Leydig cell hyperplasia is associated with multiple endocrine disturbances. Proc. Natl. Acad. Sci. U.S.A. 101, 775-780. doi: 10.1073/pnas.0305977101

Alexander, J., Benford, D., Chaudhry, Q., Hardy, A., Jeger, M. J., Luttik, R., et al. (2013). Scientific opinion on the hazard assessment of endocrine disruptors: scientific criteria for identification of endocrine disruptors and appropriateness of existing test methods for assessing effects mediated by these substances on human health and the environment. EFSA J. 11, 84-87. doi: 10.2903/j.efsa.2013.3132

Andrade, A. J., Grande, S. W., Talsness, C. E., Grote, K., Golombiewski, A., Sterner-Koch, A., et al. (2006). A dose response study following in utero and lactational exposure to di-(2-ethylheyl) phtalate (DEHP): effects on androgenic status, developmental landmarks and testicular histology in male offspring rats. Toxicology 225, 64-74. doi: 10.1016/j.tox.2006.05.007

Anway, M. D., and Skinner, M. K. (2008). Epigenetic programming of the germ line: effects of endocrine disruptors on the development of transgenerational disease. Reprod. Biomed. Online 16, 23-25. doi: 10.1016/S1472-6483(10)60553-6

Arase, S., Ishii, K., Igarashi, K., Aisaki, K., Yoshio, Y., Matsushima, A., et al. (2011). Endocrine disrupter bisphenol A increases in situ estrogen production in the mouse urogenital sinus. Biol. Reprod. 84, 734-742. doi: 10.1095/biolreprod. 110.087502

Balabanic, D., Rupnik, M., and Klemencic, A. K. (2011). Negative impact of endocrine-disrupting compounds on human reproductive health. Reprod. Fertil. Dev. 23, 403-416. doi: 10.1071/RD09300

Barker, D. J. (2004). The developmental origins of adult disease. J. Am. Coll. Nutr. 23(6 Suppl.), 588S-595S. doi: 10.1080/07315724.2004.10719428

Barlow, N. J., Phillips, S. L., Wallace, D. G., Sar, M., Gaido, K. W., and Foster, P. M. (2003). Quantitative changes in gene expression in fetal rat testes following exposure to di(n-butyl) phthalate. Toxicol. Sci. 73, 431-431. doi: $10.1093 /$ toxsci $/ \mathrm{kfg} 087$

Baskin, L. S., Himes, K., and Colborn, T. (2001). Hypospadias and endocrine disruption: is there a connection? Environ. Health Perspect. 109, 1175-1183. doi: 10.1289/ehp.011091175

Biles, J. E., McNeal, T. P., Begley, T. H., and Hollifield, H. C. (1997). Determination of bisphenol-A in reusable polycarbonate food-contact plastics and migration to food simu lating liquids. J. Agric. Food Chem. 45, 3541-3544. doi: 10.1021/jf970072i

Blount, B. C., Silva, M. J., Caudill, S. P., Needham, L. L., Pirkle, J. L., Sampson, E. J., et al. (2000). Levels of seven urinary phthalate metabolites in a human reference population. Environ. Health Perspect. 108, 979-982. doi: 10.1289/ehp.00108979

Boekelheide, K., Kleymenova, E., Liu, K., Swanson, C., and Gaido, K. W. (2009). Dose-dependent effects on cell proliferation, seminiferous tubules, and male germ cells in the fetal rat testis following exposure to di(n-butyl) phthalate. Microsc. Res. Tech. 72, 629-638. doi: 10.1002/jemt.20684

Boisen, K. A., Kaleva, M., Main, K. M., Virtanen, H. E., Haavisto, A. M., Schmidt, I. M., et al. (2004). Difference in prevalence of congenital cryptorchidism in infants between two Nordic countries. Lancet 363, 1264-1269. doi: $10.1016 /$ S0140-6736(04)15998-9
Botelho, G. G., Golin, M., Bufalo, A. C., Morais, R. N., Dalsenter, P. R., and Martino-Andrade, A. J. (2009). Reproductive effects of di(2ethylhexyl)phthalate in immature malerats and its relation to cholesterol, testosterone, and thyroxin levels. Arch. Environ. Con. Toxicol. 57, 777-784. doi: $10.1007 / \mathrm{s} 00244-009-9317-8$

Bretveld, R., Brouwers, M., Ebisch, I., and Roeleveld, N. (2007). Influence of pesticides on male fertility. Scand. J. Work Environ. Health 33, 13-28. doi: 10.5271/sjweh.1060

Brennan, J., and Capel, B. (2004). One tissue, two fates: molecular genetic events that underlie testis versus ovary development. Nat. Rev. Genet. 5, 509-521. doi: $10.1038 / \operatorname{nrg} 1381$

Calafat, A. M., Kuklenyik, Z., Reidy, J. A., Caudill, S. P., Ekong, J., and Needham, L. L. (2005). Urinary concentrations of bisphenol A and 4-nonylphenol in a human reference population. Environ. Health. Perspect. 113, 391-395. doi: 10.1289/ehp.7534

Cao, J., Rebuli, M. E., Rogers, J., Todd, K. L., Leyrer, S. M., Ferguson, S. A., et al. (2013). Prenatal bisphenol A exposure alters sex-specific estrogen receptor expression in the neonatal rat hypothalamus and amygdala. Toxicol. Sci. 133, 157-173 doi: 10.1093/toxsci/kft035

Carlsen, E., Giwercman, A., Keiding, N., and Skakkebaek, N. E. (1992). Evidence for decreasing quality of semen during pas 50 years. BMJ 305, 609-613.

Carlsen, E., Swan, S. H., Petersen, J. H., and Skakkebaek, N. E. (2005). Longitudinal changes in semen parameters in young Danish men from the Copenhagen area. Hum. Reprod. 20, 942-949. doi: 10.1093/humrep/deh704

Carruthers, C. M., and Foster, P. M. (2005). Critical window of male reproductive tract development in rats following gestational exposure to di-n-butyl phthalate. Birth Defects Res. B Dev. Reprod. Toxicol. 74, 277-285. doi: 10.1002/bdrb.20050

Chen, X., An, H., Ao, L., Sun, L., Liu, W., Zhou, Z., et al. (2011). The combined toxicity of dibutyl phthalate and benzo(a)pyrene on the reproductive system of male Sprague Dawley rats in vivo. J. Hazad. Mater. 186, 835-841. doi: 10.1016/j.jhazmat.2010.11.078

Chitra, K. C., Latchoumycandane, C., and Mathur, P. P. (2002). Effect of nonylphenol on the antioxidant system in epididymal sperm of rats. Arch. Toxicol. 76, 545-551. doi: 10.1007/s00204-002-0372-4

Christiansen, S., Kortenkamp, A., Axelstad, M., Boberg, J., Scholze, M., Jacobsen, P. R., et al. (2012). Mixtures of endocrine disrupting contaminants modelled on human high end exposures: an exploratory study in rats. Int. J. Androl. 35, 303-316. doi: 10.1111/j.1365-2605.2011.01242.x

Committee on the Health Risks of Phthalates, N. R. C. (2008). Phthalates and Cumulative Risk Assessment: The Task Ahead. Washington, DC: The National Academies Press.

Cortes, D., Thorup, J., and Visfeldt, J. (2003). Multinucleated spermatogonia in cryptorchid boys: a possible association with an increased risk of testicular malignancy later in life? APMIS 111, 25-30. doi: 10.1034/j.16000463.2003.11101051.x

Culty, M., Thuillier, R., Li, W., Wang, Y., Martinez-Arguelles, D. B., Benjamin, C. G., et al. (2008). In utero exposure to di-(2-ethylhexyl) phthalate exerts both short-term and long-lasting suppressive effects on testosterone production in the rat. Biol. Reprod. 78, 1018-1028. doi: 10.1095/biolreprod.107.065649

Dalsenter, P. R., Santana, G. M., Grande, S. W., Andrade, A. J., and Araujo, S. L. (2006). Phthalate affect the reproductive function and sexual behavior of male Wistar rats. Hum. Exp. Toxicol. 25, 297-303. doi: 10.1191/0960327105ht624oa

Darnerud, P. O. (2008). Brominated flame retardants as possible endocrine disrupters. Int. J. Androl. 31, 152-160. doi: 10.1111/j.1365-2605.2008.00869.x

Dees, J. H., Gazouli, M., and Papadopoulos, V. (2001). Effect of mono-ethylhexyl phthalate on MA-10 Leydig tumor cells. Reprod. Toxicol. 15, 171-187. doi: 10.1016/S0890-6238(01)00110-1

De Jager, C., Bornman, M. S., and Oosthuizen, J. M. (1999). The effect of p-nonylphenol on the fertility potential of male rats after gestational, lactational and direct exposure. Andrologia 31, 107-113. doi: 10.1046/j.14390272.1999.00246.x

del Mazo, J., Brieño-Enrìquez, M. A., Garc’a-López, J., López-Fernández, L. A., and De Felici, M. (2013). Endocrine disruptors, gene deregulation and male germ cell tumors. Int. J. Dev. Biol. 57, 225-239. doi: 10.1387/ijdb.130042jd

Desdoits-Lethimonier, C., Albert, O., Le Bizec, B., Perdu, E., Zalko, D., Courant, F., et al. (2012). Human testis steroidogenesis is inhibited by phthalates. Hum. Reprod. 27, 1451-1459. doi: 10.1093/humrep/des069

Diamanti-Kandarakis, E., Bourguignon, J. P., Giudice, L. C., Hauser, R., Prins, G. S., Soto, A. M., et al. (2009). Endocrine disrupting chemicals: an endocrine 
society scientific statement. Endocr. Rev. 30, 293-342. doi: 10.1210/er.20 09-0002

Dolk, H., Vrijheid, M., Armstrong, B., Abramsky, L., Bianchi, F., Garne, E., et al. (1998). Risk of congenital anomalies near hazardous-waste landfill sites in Europe: the EUROHAZCON study. Lancet 352, 423-427. doi: 10.1016/S01406736(98)01352-X

Doull, J., Cattley, R., Elcombe, C., Lake, B. G., Swenberg, J., Wilkinson, C., et al. (1999). A cancer risk assessment of $\operatorname{di}(2$-ethylhexyl)phthalate: application of the new U.S. EPA risk; assessment guidelines. Regul. Toxicol. Pharmacol. 29, 327-357. doi: 10.1006/rtph.1999.1296

Duty, S. M., Singh, N. P., Silva, M. J., Barr, D. B., Brock, J. W., Ryan, L., et al. (2003). The relationship between environmental exposures to phthalates and DNA damage in human sperm using the neutral comet assay. Environ. Health Perspect. 111, 1164-1169. doi: 10.1289/ehp.5756

Duty, S. M., Calafat, A. M., Silva, M. J., Ryan, L., and Hauser, R. (2005). Phthalate exposure and reproductive hormones in adult men. Hum. Reprod. 20, 604-610. doi: 10.1093/humrep/deh656

EC-SCF. (2006). Opinion of the Scientific Panel on Food Additives, Flavourings, Processing Aids and Materials in Contact with Food on a request from the Commission related to 2,2-BIS(4-HYDROXYPHENYL) PROPANE (Bisphenol A). EFSA J. 428, 1-75.

Edwards, T. M., and Myers, J. P. (2007). Environmental exposures and gene regulation in disease etiology. Environ. Health Perspect. 115, 1264-1270. doi: 10.1289/ehp.9951

Elliott, P., Briggs, D., Morris, S., de Hoogh, C., Hurt, C., Jensen, T. K., et al. (2001). Risk of adverse birth outcomes in populations living near landfill sites. BMJ 323, 363-368. doi: 10.1136/bmj.323.7309.363

Ema, M., Miyawaki, E., and Kawashima, K. (2000). Critical period for adverse effects on development of reproductive system in male offspring of rats given di- $n$-butyl phthalate during late pregnancy. Toxicol. Lett. 111, 271-278. doi: 10.1016/S0378-4274(99)00192-7

Fan, J., Traore, K., Li, W., Amri, H., Huang, H., Wu, C., et al. (2010). Molecular mechanisms mediating the effect of mono-(2-ethylhexyl)phthalate on hormone-stimulated steroidogenesis in MA-10 mouse tumor Leydig cells. Endocrinology 151, 3348-3362. doi: 10.1210/en.2010-0010

Fenichel, P., Dechaux, H., Harthe, C., Gal, J., Ferrari, P., Pacini, P., et al. (2012) Unconjugated bisphenol A cord blood levels in boys with descended or undescended testes. Hum. Reprod. 27, 983-990. doi: 10.1093/humrep/der451

Fernandez, M. (2010). "Endocrine disruptors and semen quality," in Presentation at ESHRE Annual Meeting (Rome).

Fisher, J. S. (2004). Environmental anti-androgens and male reproductive health: focus on phthalates and testicular dysgenesis syndrome. Reproduction 127, 305-315. doi: 10.1530/rep.1.00025

Fisher, J. S., Macpherson, S., Marchetti, N., and Sharpe, R. M. (2003). Human 'testicular dysgenesis syndrome': a possible model using in utero exposure of the rat to dibutyl phthalate. Hum. Reprod. 18, 1383-1394. doi: 10.1093/humrep/ $\operatorname{deg} 273$

Foster, P. M. (2006). Disruption of reproductive development in male rat offspring following in utero exposure to phthalate esters. Int. J. Androl. 29, 140-147. doi: 10.1111/j.1365-2605.2005.00563.x

Frederiksen, H., Aksglaede, L., Sorensen, K., Skakkebaek, N. E., Juul, A., and Andersson, A. M. (2011). Urinary excretion of phthalate metabolites in 129 healthy Danish children and adolescents: estimation of daily phthalate intake. Environ. Res. 111, 656-663. doi: 10.1016/j.envres.2011.03.005

Garry, V. F., Harkins, M. E., Erickson, L. L., Long-Simpson, L. K., Holland, S. E., and Burroughs, B. L. (2002). Birth defects, season of conception, and sex of children born to pesticide applicators living in the Red River Valley of Minnesota, USA. Environ. Health Perspect. 110, 441-449. doi: 10.1289/ehp.021 $10 \mathrm{~s} 3441$

Gill, W. B., Schumacher, G. F., Bibbo, M., Straus, F. H. II, and Schoenberg, H. W. (1979). Association of diethylstilbestrolexposure in utero with cryptorchidism, testicular hypoplasiaand semen abnormalities. J. Urol. 122, 36-39.

Göen, T., Dobler, L., Koschorreck, J., Müller, J., Wiesmüller, G. A., Drexler, H., et al. (2011). Trends of the internal phthalate exposure of young adults in Germanyfollow-up of a retrospective human biomonitoring study. Int. J. Hyg. Environ. Health. 215, 36-45.

Gong, Y., and Han, X. D. (2006). Nonylphenol-induced oxidative stress and cytotoxicity in testicular Sertoli cells. Reprod. Toxicol. 22, 623-630. doi: 10.1016/j.reprotox.2006.04.019
Grady, R., and Sathyanarayana, S. (2012). An update on phthalates and male reproductive development and function. Curr. Urol. Rep. 13, 307-310. doi: 10.1007/s11934-012-0261-1

Gray, L. E. Jr., Ostby, J., Furr, J., Price, M., Veeramachaneni, D. N., and Parks, L. (2000). Perinatal exposure to the phthalates DEHP, BBP, and DINP, but not DEP, DMP, or DOTP, alters sexual differentiation of the male rat. Toxicol. Sci. 58, 350-365. doi: 10.1093/toxsci/58.2.350

Gray, L. E., Ostby, J., Furr, J., Wolf, C. J., Lambright, C., Parks, L., et al. (2001). Effects of environmental antiandrogens on reproductive development in experimental animals. Hum. Reprod. Update 7, 248-264. doi: 10.1093/humupd/7.3.248

Green, R., Hauser, R., Calafat, A. M., Weuve, J., Schettler, T., Ringer, S., et al. (2005). Use of di(2-ethylhexyl) phthalate-containing medical products and urinary levels of mono(2-ethylhexyl) phthalate in neonatal intensive care unit infants. Environ. Health Perspect. 113, 1222-1225. doi: 10.1289/ehp.7932

Guenther, K., Heinke, V., Thiele, B., Kleist, E., Prast, H., and Raecker, T. (2002) Endocrine disrupting nonylphenols are ubiquitous in food. Environ. Sci. Technol. 36, 1676-1680. doi: 10.1021/es010199v

Gupta, R. K., Singh, J. M., Leslie, T. C., Meachum, S., Flaws, J. A., and Yao, H. H. (2010). Di-(2-ethylhexyl) phthalate and mono-(2-ethylhexyl) phthalate inhibit growth and reduce estradiol levels of antral follicles in vitro. Toxicol. Appl. Pharmacol. 242, 224-230. doi: 10.1016/j.taap.2009.10.011

Hanaoka, T., Kawamura, N., Hara, K., and Tsugane, S. (2002). Urinary bisphenol $\mathrm{A}$ and plasma hormone concentrations in male workers exposed to bisphenol A diglycidyl ether and mixed organic solvents. Occup. Environ. Med. 59, 625-628. doi: 10.1136/oem.59.9.625

Hannas, B. R., Furr, J., Lambright, C. S., Wilson, V. S., Foster, P. M., Gray, L. E., et al. (2011). Dipentyl phthalate dosing during sexual differentiation disrupts fetal testis function and postnatal development of the male Sprague Dawley rat with greater relative potency than other phthalates. Toxicol. Sci. 120, 184-193. doi: 10.1093/toxsci/kfq386

Hauser, R., Meeker, J. D., Duty, S., Silva, M. J., and Calafat, A. M. (2006). Altered semen quality in relation to urinary concentrations of phthalate monoester and oxidative metabolites. Epidemiology 17, 682-691. doi: 10.1097/01.ede.0000235996.89953.d7

Hauser, R., Meeker, J. D., Singh, N. P., Silva, M. J., Ryan, L., Duty, S., et al. (2007). DNA damage in human sperm is related to urinary levels of phthalate monoester and oxidative metabolites. Hum. Reprod. 22, 688-695. doi: 10.1093/humrep/del428

Hayes, T. B., Anderson, L. L., Beasley, V. R., de Solla, S. R., Iguchi, T., Ingraham, H., et al. (2011). Demasculinization and feminization of male gonads by atrazine: consistent effects across vertebrate classes. J. Steroid Biochem. Mol. Biol. 127, 64-73. doi: 10.1016/j.jsbmb.2011.03.015

Hass, U., Boberg, J., Christiansena, S., Jacobsen, P. R., Vinggaard, A. M., Taxvig, C., et al. (2012). Adverse effects on sexual development in rat offspring after low dose exposure to a mixture of endocrine disrupting pesticides. Reprod. Toxicol. 34, 261-274. doi: 10.1016/j.reprotox.2012.05.090

Hass, U., Scholze, M., Christiansen, S., Dalgaard, M., Vinggaard, A. M., Axelstad, M., et al. (2007). Combined exposure to anti-androgens exacerbates disruption of sexual differentiation in the rat. Environ. Health Perspect. 115, 122-128. doi: 10.1289/ehp. 9360

Hauser, R., and Calafat, A. M. (2005). Phthalates and human health. Occup. Environ. Med. 62, 806-818. doi: 10.1136/oem.2004.017590

Herath, C. B., Jin, W., Watanabe, G., Arai, K., Suzuki, A. K., and Taya, K. (2004). Adverse effects of environmental toxicants, octylphenol and bisphenol A, on male reproductive functions in pubertal rats. Endocrine 25, 163-172. doi: 10.1385/ENDO:25:2:163

Herbst, A. L., Ulfelder, H., and Poskanzer, D. C. (1971). Adenocarcinoma of the vagina. Association of maternal stilbestrol therapy with tumor appearance in young women. New Engl. J. Med. 284, 878-881. doi: 10.1056/NEJM197104222841604

Hess, R. A. (2003). Estrogen in the adult male reproductive tract: a review. Reprod. Biol. Endocrinol. 1:52. doi: 10.1186/1477-7827-1-52

Hines, E. P., Calafat, A. M., Silva, M. J., Mendola, P., and Fenton, S. E. (2009). Concentrations of phthalate metabolites in milk, urine, saliva and serum of lactating North Carolina women. Environ. Health Perspect. 117, 86-92. doi: 10.1289/ehp. 11610

Ho, S. M., Tang, W. Y., Belmonte de Frausto, J., and Prins, G. S. (2006). Developmental exposure to estradiol and bisphenol A increases susceptibility 
to prostate carcinogenesis and epigenetically regulates phosphodiesterase type 4 variant 4. Cancer Res. 66, 5624-5632. doi: 10.1158/0008-5472.CAN-06-0516

Hoei-Hansen, C. E., Holm, M., Rajpert-De Meyts, E., and Skakkabaek, N. E. (2003). Histological evidence of testicular dysgenesis in contralateral biopsies from 218 patients with testicular germ cell cancer. J. Pathol. 200, 370-374. doi: 10.1002/path.1372

Hogan, N. S., Currie, S., LeBlanc, S., Hewitt, L. M., and MacLatchy, D. L. (2010). Modulation of steroidogenesis and estrogen signalling in the estuarine killifish (Fundulus heteroclitus) exposed to ethinylestradiol. Aquat. Toxicol. 98, 148-156. doi: 10.1016/j.aquatox.2010.02.002

Holm, M., Rajpert-De Meyts, E., Andersson, A. M., and Skakkebaek, N. E. (2003). Leydig cell micronodules are a common finding in testicular biopsies from men with impaired spermatogenesis and are associated with decreased testosterone/LH ratio. J. Pathol. 199, 378-386. doi: 10.1002/path.1309

Huang, P. C., Kuo, P. L., Chou, Y. Y., Lin, S. Y., and Lee, C. C. (2009). Association between prenatal exposure to phthalates and the health of newborns. Environ. Int. 35, 14-20. doi: 10.1016/j.envint.2008.05.012

Huang, Y. Q., Wong, C. K. C., Zheng, J. S., Bouwman, H., Barra, R., Wahlström, B., et al. (2012). Bisphenol A (bisphenol A) in China: a review of sources, environmental levels, and potential human health impacts. Environ. Int. 42, 91-99. doi: 10.1016/j.envint.2011.04.010

Huber, W. W., Grasl-Kraupp, B., and Schulte-Hermann, R. (1996). Hepatocarcinogenic potential of di(2-ethylhexyl)phthalate in rodents and its implications on human risk. Crit. Rev. Toxicol. 26, 365-481. doi: 10.3109/ 10408449609048302

Hutchison, G. R., Scott, H. M., Walker, M., McKinnell, C., Ferrara, D., Mahood, I. K., et al. (2008). Sertoli cell development and function in an animal model of testicular dysgenesis syndrome. Biol. Reprod. 78, 352-360. doi: 10.1095/biolreprod.107.064006

Ikezuki, Y., Tsutsumi, O., Takai, Y., Kamei, Y., and Taketani, Y. (2002). Determination of bisphenol A concentrations in human biological fluids reveals significant early prenatal exposure. Hum. Reprod. 17, 2839-2841. doi: 10.1093/humrep/17.11.2839

Inoue, K., Kondo, S., Yoshie, Y., Kato, K., Yoshimura, Y., Horie, M., et al. (2001). Migration of 4-nonylphenol from polyvinyl chloride food packaging films into food simulants and foods. Food Addit. Contam. 18, 157-164. doi: $10.1080 / 02652030010018930$

Inoue, K., Wada, M., Higuchi, T., Oshio, S., Umeda, T., Yoshimura, Y., et al. (2002). Application of liquid chromatography-mass spectrometry to the quantifi cation of bisphenol A in human semen. J. Chromatogr. B Analyt. Technol. Biomed. Life Sci. 773, 97-102. doi: 10.1016/S1570-0232(02)00101-0

Irgens, A., Kruger, K., Skorve, A. H., and Irgens, L. M. (2000). Birth defects and paternal occupational exposure. Hypotheses tested in a record linkage based dataset. Acta Obstet. Gynecol. Scand. 79, 465-470. doi: 10.1080/j.16000412.2000.079006465.x

Isling, L. K., Boberg, J., Jacobsen, P. R., Mandrup, K. R., Axelstad, M., Christiansen, S., et al. (2014). Late-life effects on rat reproductive system after developmental exposure to mixtures of endocrine disrupters. Reproduction 147, 465-476. doi: 10.1530/REP-13-0448

Jacobsen, P. R., Axelstad, M., Boberg, J., Isling, L. K., Christiansen, S., Mandrup, K. R., et al. (2012). Persistent developmental toxicity in rat offspring after low dose exposure to a mixture of endocrine disrupting pesticides. Reprod. Toxicol. 34, 237-250. doi: 10.1016/j.reprotox.2012.05.099

Jager, C., Bornman, M. S., and Oosthuizen, J. M. (1999). The effect of pnonylphenol on the fertility potential of male rats after gestational, lactational and direct exposure. Andrologia 31, 107-113. doi: 10.1046/j.14390272.1999.00246.x

Jeng, H. A. (2014). Exposure to endocrine disrupting chemicals and male reproductive health. Front. Public Health 2:55. doi: 10.3389/fpubh.2014.00055

Jensen, T. K., Toppari, J., Keiding, N., and Skakkebaek, N. E. (1995). Do environmental estrogens contribute to the decline in male reproductive health? Clin. Chem. 41, 1896-1901.

Ji, K., Hong, S., Kho, Y., and Choi, K. (2013). Effects of bisphenol S exposure on endocrine functions and reproduction of zebrafish. Environ. Sci. Technol. 47, 8793-8800. doi: 10.1021/es400329t

Johnson, K. J., McDowell, E. N., Viereck, M. P., and Xia, J. Q. (2011). Speciesspecific dibutyl phthalate fetal testis endocrine disruption correlates with inhibition of SREBP2-dependent gene expression pathways. Toxicol. Sci. 120, 460-474. doi: $10.1093 /$ toxsci/kfr020
Johnson, K. J., Heger, N. E., and Boekelheide, K. (2012). Of mice and men (and rats): phthalate-induced fetal testis endocrine disruption is species-dependent. Toxicol. Sci. 129, 235-248. doi: 10.1093/toxsci/kfs206

Jones, H. B., Garside, D. A., Lu, R., and Roberts, J. C. (1993). The influence of phthalate esters on Leydig cell structure and function in vitro and in vivo. Exp. Mol. Pathol. 58, 179-193. doi: 10.1006/exmp.1993.1016

Jönsson, A. G., Richthoff, J., Rylande, L., Giwercman, A., and Lars, H. (2005). Urinary phthalate metabolites and biomarkers of reproductive function in young men. Epidemiology 16, 487-493. doi: 10.1097/01.ede.0000164555. 19041.01

Jurewicz, J., and Hanke, W. (2011). Exposure to phthalates: reproductive outcome and children's health. A review of epidemiological studies. Int. J. Occup. Med. Environ. Health 24, 115-141. doi: 10.2478/s13382-011-0022-2

Jurewicz, J., Radwan, M., Sobala, W., Ligocka, D., Radwan, P., Bochenek, M., et al. (2013). Human urinary phthalate metabolites level and main semen parameters, sperm chromatin structure, sperm aneuploidy and reproductive hormones. Reprod. Toxicol. 42, 232-241. doi: 10.1016/j.reprotox.2013.10.001

Kavlock, R., and Cummings, A. (2005). Mode of action: inhibition of androgen receptor function-vinclozolin-induced malformations in reproductive development. Critic. Rev. Toxicol. 35, 721-726. doi: 10.1080/10408440591007377

Kleymenova, E., Swanson, C., Boekelheide, K., and Gaido, K. W. (2005). Exposure in utero to di ( $n$-butyl) phthalate alters the vimentin cytoskeleton of fetal rat Sertoli cells and disrupts Sertoli cell-gonocyte contact. Biol. Reprod. 73, 482-490. doi: 10.1095/biolreprod.104.037184

Koch, H. M., Drexler, H., and Angerer, J. (2003). An estimation of the daily intake of di(2-ethylhexyl)phthalate (DEHP) and other phthalates in the general population. Int. J. Hyg. Environ. Health 206, 77-83. doi: 10.1078/1438-4639-00205

Koch, H. M., Preuss, R., Drexler, H., and Angerer, J. (2005). Exposure of nursery school children and their parents and teachers to di-n-butylphthalate and butylbenzylphthalate. Int. Arch. Occup. Environ. Health 78, 223-229. doi: 10.1007/s00420-004-0570-x

Kortenkamp, A. (2007). Ten years of mixing cocktails: a review of combination effects of endocrine-disrupting chemicals. Environ. Health Perspect. 115, 98-105. doi: 10.1289/ehp.9357

Kortenkamp, A., and Faust, M. (2010). Combined exposures to anti-androgenic chemicals: steps towards cumulative risk assessment. Int. J. Androl. 2, 463-474. doi: 10.1111/j.1365-2605.2009.01047.x

Kortenkamp, A., Faust, M., Scholze, M., and Backhaus, T. (2007). Low-level exposure to multiple chemicals: reason for human health concerns? Environ. Health Perspect. 115, 106-114. doi: 10.1289/ehp.9358

Knez, J. (2013). Endocrine-disrupting chemicals and male reproductive health. Reprod. Biomed. Online 26, 440-448. doi: 10.1016/j.rbmo.2013.02.005

Kristensen, P., Irgens, L. M., Andersen, A., Bye, A. S., and Sundheim, L. (1997). Birth defects among offspring of Norwegian farmers. 1967-1991. Epidemiology 8, 537-544. doi: 10.1097/00001648-199709000-00011

Lagos-Cabré, R., and Moreno, R. D. (2012). Contribution of environmental pollutants to male infertility: a working model of germ cell apoptosis induced by plasticizers. Biol. Res. 45, 5-14. doi: 10.4067/S0716-97602012000100001

Lambrot, R., Muczynski, V., Lecureuil, C., Angenard, G., Coffigny, H., Pairault, C., et al. (2009). Phthalates impair germ cell development in the human fetal testis in vitro without change in testosterone production. Environ. Health Perspect. 117, 32-37. doi: 10.1289/ehp.11146

Lang, I. A., Galloway, T. S., Scarlett, A., Henley, W. E., Depledge, M., Wallace, R. B., et al. (2008). Association of urinary bisphenol A concentration with medical disorders and laboratory abnormalities in adults. JAMA 300, 1303-1310. doi: 10.1001/jama.300.11.1303

Lange, A., Paull, G. C., Coe, T. S., Katsu, Y., Urushitani, H., Iguchi, T., et al. (2009). Sexual reprogramming and estrogenic sensitization in wild fish exposed to ethinylestradiol. Environ. Sci. Technol. 43, 1219-1225. doi: 10.1021/es802661p

Latini, G., De Felice, C., Presta, G., Del Vecchio, A., Paris, I., Ruggieri, F., et al. (2003). In utero exposure to di-(2-ethylhexyl)phthalate and duration of human pregnancy. Environ. Health Perspect. 111, 1783-1785. doi: 10.1289/ehp.6202

Latini, G., Del Vecchio, A., Massaro, M., Verrotti, A., and De Felice, C. (2006). Phthalate exposure and male infertility. Toxicology 226, 90-98. doi: 10.1016/j.tox.2006.07.011

Laurenzana, E. M., Balasubramanian, G., Weis, C., Blaydes, B., Newbold, R. R., and Delclos, K. B. (2002). Effect of nonylphenol on serum testosterone levels and testicular steroidogenic enzyme activity in neonatal, pubertal, and adult rats. Chem. Biol. Interact. 139, 23-41. doi: 10.1016/S0009-2797(01)00291-5 
Lee, P. C. (1998). Disruption of male reproductive tract development by administration of the xenoestrogen, nonylphenol, to male newborn rats. Endocrine 9, 105-111. doi: 10.1385/ENDO:9:1:105

Lee, P. C., Arndt, P., and Nickels, K. C. (1999). Testicular abnormalities in male rats after lactational exposure to nonylphenols. Endocrine 11, 61-68. doi: 10.1385/ENDO:11:1:61

Lee, H.-R., Jeung, E.-B., Cho, M.-H., Kim, T.-H., Leung, P. C. K., and Choi, K.C. (2013). Molecular mechanism(s) of endocrine-disrupting chemicals and their potent oestrogenicity in diverse cells and tissues that express oestrogen receptors. J. Cell. Mol. Med. 17, 1-11. doi: 10.1111/j.1582-4934.2012.01649.x

Lehmann, K. P., Phillips, S., Sar, M., Foster, P. M., and Gaido, K. W. (2004). Dosedependent alterations in gene expression and testosterone synthesis in the fetal testes of male rats exposed to di (n-butyl) phthalate. Toxicol. Sci. 81, 60-68. doi: $10.1093 /$ toxsci/kfhl69

Lejeune, H., Habert, R., and Saez, J. M. (1998). Origin, proliferation and differentiation of Leydig cells. J. Mol. Endocrinol. 20, 1-25. doi: 10.1677/jme.0.0200001

Li, D. K., Zhou, Z., Miao, M., He, Y., Wang, J., Ferber, J., et al. (2011). Urine bisphenol-A (BPA) level in relation to semen quality. Fertil. Steril. 95, 625-630. doi: 10.1016/j.fertnstert.2010.09.026

Li, M. W., Mruk, D. D., Lee, W. M., and Cheng, C. Y. (2009). Disruption of the blood-testis barrier integrity by bisphenol A in vitro: is this a suitable model for studying blood-testis barrier dynamics? Int. J. Biochem. Cell Biol. 41, 2302-2314. doi: 10.1016/j.biocel.2009.05.016

Liu, C., Duan, R., Li, R., Xu, S., Zhang, L., Chen, C., et al. (2013). Exposure to bisphenol A disrupts meiotic progression during spermatogenesis in adult rats through estrogen-like activity. Cell Death Dis. 4, e676. doi: 10.1038/cddis.2013.203

Liu, K., Lehmann, K. P., Sar, M., Young, S. S., and Gaido, K. W. (2005). Gene expression profiling following in utero exposure to phthalate esters reveals new gene targets in the etiology of testicular dysgenesis. Biol. Reprod. 73, 180-192. doi: 10.1095/biolreprod.104.039404

Lovekamp, T. N., and Davis, B. J. (2001). Mono-(2-ethylhexyl) phthalate suppresses aromatase transcript levels and estradiol production in cultured rat garnulosa cells. Toxicol. Appl. Pharmacol. 172, 217-224. doi: 10.1006/taap.2001.9156

Magre, S., and Jost, A. (1991). Sertoli cells and testicular differentiation in the rat fetus. J. Electron. Microsc. Tech. 19, 172-188. doi: 10.1002/jemt.1060190205

Mahood, I. K., Scott, H. M., Brown, R., Hallmark, N.,Walker, M., and Sharpe, R. M. (2007). In utero exposure to di(n-butyl) phthalate and testicular dysgenesis: comparison of fetal and adult end points and their dose sensitivity. Environ. Health Perspect. 15, 55-61. doi: 10.1289/ehp.9366

Main, K. M., Kivirana, H., Virtanen, H. E., Sundqvist, E., Tuomisto, J. T., Vartiainen, T., et al. (2007). Flame retardants in placenta and breast milk and cryptorchidism in newborn boys. Environ. Health Perspect. 115, 1519-1526. doi: 10.1289/ehp. 9924

Main, K. M., Mortensen, G. K., Kaleva, M. M., Boisen, K. A., Damgaard, I. N., Chellakooty, M., et al. (2006). Human breast milk contamination with phthalates and alterations of endogenous reproductive hormones in infants three months of age. Environ. Health Perspect. 114, 270-276. doi: 10.1289/ehp.8075

Marques-Pinto, A., and Carvalho, D. (2013). Human infertility: are endocrine disruptors to blame? Endocr. Connect. 2, R15-R29. doi: 10.1530/EC-13-0036

Martinez-Arguelles, D. B., Campioli, E., Culty, M., Zirkin, B. R., and Papadopoulos, V. (2013). Fetal origino $\mathrm{f}$ endocrine dysfunction in the adult: the phthalate model. J. Steroid Biochem. Mol. Biol. 137, 5-17. doi: 10.1016/j.jsbmb.2013.01.007

Martinez-Arguelles, D. B., Culty, M., Zirkin, B. R., and Papadopoulos, V. (2009). In utero expo-sure to di-(2-ethylhexyl) phthalate decreases mineralocorticoid receptor expression in the adult testis. Endocrinology 150, 5575-5585. doi: 10.1210/en.2009-0847

Martinez-Arguelles, D. B., Guichard, T., Culty, M., Zirkin, B. R., and Papadopoulos, V. (2011). In utero exposure to the antiandrogen di-(2-ethylhexyl) phthalate decreases adrenal aldosterone production in the adult rat. Biol. Reprod. 85, 51-61. doi: 10.1095/biolreprod.110.089920

Massart, F., and Saggese, G. (2009). Sex steroidal targets \& genetic susceptibility to idiopathic cryptorchidism. Pediatr. Endocrinol. Rev. 6, 481-490.

Mastroiacovo, P., Spagnolo, A., Marni, E., Meazza, L., Bertolini, R., Segni, G., et al. (1988). Birth defects in the Seveso area after TCDD contamination. JAMA 259, 1668-1672.

McClusky, L. M., de Jager, C., and Bornman, M. S. (2007). Stage-related increase in the proportion of apoptotic germ cells and altered frequencies of stages in the spermatogenic cycle following gestational, lactational, and direct exposure of male rats to p-nonylphenol. Toxicol. Sci. 95, 249-256. doi: 10.1093/toxsci/kfl141

McKee, R. H., Butala, J. H., David, R. M., and Gans, G. (2004). NTP center for the evaluation ofrisks to human reproduction reports on phthalates: addressing the data gaps. Reprod. Toxicol. 18, 1-22. doi: 10.1016/j.reprotox.2003.09.002

McLachlan, J. A., Newbold, R. R., and Bullock, B. (1975). Reproductive tract lesions in male mice exposed prenatally to diethylstilbestrol. Science 190, 991-992. doi: 10.1126/science. 242076

Meeker, J. D., Ehrlich, S., Toth, T. L., Wright, D. L., Calafat, A. M., Trisini, A. T., et al. (2010). Semen quality and sperm DNA damage in relation to urinary bisphenol A among men from an infertility clinic. Reprod. Toxicol. 30, 532-539. doi: 10.1016/j.reprotox.2010.07

Mendiola, J., Jørgensen, N., Andersson, A., Calafat, A., Silva, M., Redmon, J., et al. (2011). Associations between urinary metabolites of di(2-ethylhexyl) phthalate and reproductive hormones in fertile men. Int. J. Androl. 34, 369-378. doi: 10.1111/j.1365-2605.2010.01095.x

Moody, S., Goh, H., Bielanowicz, A., Rippon, P., Loveland, K. L., and Itman, C. (2013). Prepubertal mouse testis growth and maturation and androgen production are acutely sensitive to di- $n$-butyl phthalate. Endocrinology 154, 3460-3475. doi: 10.1210/en.2012-2227

Moore, R. W., Rudy, T. A., Lin, T. M., Ko, K., and Peterson, R. E. (2001). Abnormalities of sexual development in male rats with in utero and lactational exposure to the antiandrogenic plasticizer di(2-ethylhexyl) phthalate. Environ. Health Perspect. 109, 229-379. doi: 10.1289/ehp.01109229

Moral, R., Wang, R., Russo, I. H., Lamartiniere, C. A., Pereira, J., and Russo, J. (2008). Effect of prenatal exposure to the endocrine disruptor bisphenol A on mammary gland morphology and gene expression signature. J. Endocrinol. 196, 101-112. doi: 10.1677/JOE-07-0056

Mylchreest, E., Sar, M., Wallace, D. G., and Foster, P. M. (2002). Fetal testosterone insufficiency and abnormal proliferation of Leydig cells and gonocytes in rats exposed to di(n-butyl) phthalate. Reprod. Toxicol. 16, 19-28. doi: 10.1016/S0890-6238(01)00201-5

Mylchreest, E., Wallace, D. G., Cattley, R. C., and Foster, P. M. (2000). Dosedependent alterations in androgen-regulated male reproductive development in rats exposed to di(n-butyl) phthalate during late gestation. Toxicol. Sci. 55, 143-151. doi: 10.1093/toxsci/55.1.143

Nagao, T., Wada, K., Marumo, H., Yoshimura, S., and Ono, H. (2001). Reproductive effects of nonylphenol in rats after gavage administration: a two-generation study. Reprod. Toxicol. 15, 293-315. doi: 10.1016/S0890-6238(01)00123-X

Nagel, S. C., vom Saal, F. S., Thayer, K. A., Dhar, M. G., Boechler, M., and Welshons, W. V. (1997). Relative binding affinity-serum modified access (RBA-SMA) assay predicts the relative in vivo bioactivity of the xenoestrogens bisphenol A and octylphenol. Environ. Health Perspect. 105, 70-76. doi: 10.1289/ehp. 9710570

Nistal, M., Gonzalez-Peramato, P., Regadera, J., Serrano, A., Tarin, V., and De Miguel, M. (2006). Primary testicular lesions are associated with testicular germ cell tumors of adult men. Am. J. Surg. Pathol. 30, 1260-1268. doi: 10.1097/01.pas.0000213361.10756.08

Nordkap, L., Nordstrom Joensen, U., Blomberg Jensen, M., and Jørgensen, N. (2012). Regional differences and temporal trends in male reproductive health disorders: semen quality may be a sensitive marker of environmental exposures. Mol. Cell. Endocrinol. 355, 221-230. doi: 10.1016/j.mce.2011.05.048

N’Tumba-Byn, T., Moison, D., Lacroix, M., Lecureuil, C., Lesage, L., Prud'homme, S. M., et al. (2012). Differential effects of bisphenol A and diethylstilbestrol on human, rat and mouse fetal Leydig cell function. PLoS ONE 7:e51579. doi: 10.1371/journal.pone.0051579

Ogura, Y., Ishii, K., Kanda, H., Kanai, M., Arima, K., Wang, Y., et al. (2007). Bisphenol A induces permanent squamous change in mouse prostatic epithelium. Differentiation 75, 745-756. doi: 10.1111/j.1432-0436.2007.00177.x

Padungtod, C., Savitz, D. A., Overstreet, J. W., Christiani, D. C., Ryan, L. M., and $\mathrm{Xu}, \mathrm{X} .(2000)$. Occupational pesticide exposure and semen quality among Chinese workers. J. Occup. Environ. Med. 42, 982-992. doi: 10.1097/00043764200010000-00004

Pan, G., Hanaoka, T., Yoshimura, M., Zhang, S., Wang, P., Tsukino, H., et al. (2006) Decreased serum free testosterone in workers exposed to highl evels of di-nbutyl phthalate (DBP) and di-2-ethyl hexyl phthalate (DEHP): across-sectional study in China. Environ. Health Perspect. 114, 1643-1648. doi: 10.1289/ehp.9016

Pant, N., Pant, A., Shukla, M., Mathur, N., Gupta, Y., and Saxena, D. (2011). Environmental and experimental exposure of phthalate esters: the 
toxicological consequence on human sperm. Hum. Exp. Toxicol. 30, 507-514. doi: 10.1177/0960327110374205

Park, J. D., Sultan, S. M. H., and Klaassen, C. D. (2002). Testicular toxicity of di(2ethylhexyl) phthalate in young Sprague-Dawley rats. Toxicology 171, 105-115. doi: 10.1016/S0300-483X(01)00567-4

Park, S. Y., and Jameson, J. L. (2005). Minireview: transcriptional regulation of gonadal development and differentiation. Endocrinology 146, 1035-1042. doi: 10.1210/en.2004-1454

Parks, L. G., Ostby, J. S., Lambright, C. R., Abbott, B. D., Klinefelter, G. R., Barlow, N. J., et al. (2000). The plasticizer diethylhexyl phthalate induces malformations by decreasing fetal testosterone synthesis during sexual differentiation in the male rat. Toxicol. Sci. 58, 339-349. doi: 10.1093/toxsci/58.2.339

Phillips, K. P., and Tanphaichitr, N. (2008). Human exposure to endocrine disrupters and semen quality. J. Toxicol. Environ. Health B Crit. Rev. 11, 188-220. doi: 10.1080/10937400701873472

Plonait, S. L., Nau, H., Maier, R. F., Wittfoht, W., and Obladen, M. (1993). Exposure of newborn infants to di-(2-ethylhexyl)-phthalate and 2-ethylhexanoic acid following exchange transfusion with polyvinylchloride catheters. Transfusion 33 , 598-605. doi: 10.1046/j.1537-2995.1993.33793325058.x

Plummer, S., Sharpe, R. M., Hallmark, N., Mahood, I. K., and Elcombe, C. (2007). Time-dependent and compartment-specific effects of in utero exposure to $\operatorname{di}(n-$ butyl) phthalate on gene/protein expression in the fetal rat testis as revealed by transcription profiling and laser capture microdissection. Toxicol. Sci. 97, 520-532. doi: 10.1093/toxsci/kfm062

Pocar, P., Fiandanese, N., Secchi, C., Berrini, A., Fischer, B., Schmidt, J. S., et al. (2012). Effects of polychlorinated biphenyls in CD-1 mice: reproductive toxicity and intergenerational transmission. Toxicol. Sci. 126, 213-226. doi: 10.1093/toxsci/kfr327

Ponzo, O. J., and Carbone, S. (2013). Evidence of reproductive disruption associated with neuroendocrine changes induced by UV-B filters, phthalates and nonylphenol during sexual maturation in rats of both gender. Toxicology 311, 41-51. doi: 10.1016/j.tox.2013.05.014

Richter, C. A., Birnbaum, L. S., Farabollini, F., Newbold, R. R., Rubin, B. S., Talsness, C. E., et al. (2007). In vivo effects of bisphenol A in laboratory rodent studies. Reprod. Toxicol. 24, 199-224. doi: 10.1016/j.reprotox.2007.06.004

Rubin, B. S. (2011). Bisphenol A: an endocrine disruptor with widespread exposure and multiple effects. J. Steroid Biochem. Mol. Biol. 127, 27-34. doi: 10.1016/j.jsbmb.2011.05.002

Rudel, R. A., and Perovich, L. J. (2009). Endocrine disrupting chemicals in indoor and outdoor air. Atmos. Environ. 43, 170-181. doi: 10.1016/j.atmosenv.2008. 09.025

Salian, S., Doshi, T., and Vanage, G. (2009). Neonatal exposure of male rats to bisphenol A impairs fertility and expression of sertoli cell junctional proteins in the testis. Toxicology 265, 56-67. doi: 10.1016/j.tox.2009.09.012

Saunders, P. T., Majdic, G., Parte, P., Millar, M. R., Fisher, J. S., Turner, K. J., et al. (1997). Fetal and perinatal influence of xenoestrogens on testis gene expression. Adv. Exp. Med. Biol. 424, 99-110. doi: 10.1007/978-1-4615-5913-9_19

Schnitzer, P. G., Olshan, A. F., and Erickson, J. D. (1995). Paternal occupation and risk of birth defects in offspring. Epidemiology 6, 577-583. doi: 10.1097/00001648-199511000-00003

Schug, T. T., Janesick, A., Blumberg, B., and Heindel, J. J. (2011). Endocrine disrupting chemicals and disease susceptibility. J. Steroid Bichem. 127, 204-215. doi: 10.1016/j.jsbmb.2011.08.007

Scott, H. M., Hutchinson, G. R., Jobling, M. S., McKinnel, C., Drake, A. J., and Sharpe, R. M. (2008). Relationship between androgen action in the "male programming window," fetal Sertoli cell number, and adult testis size in the rat. Endocrinology 149, 5280-5287. doi: 10.1210/en.2008-0413

Scott, H. M., Hutchison, G. R., Mahood, I. K., Hallmark, N., Welsh, M., De Gendt, K., et al. (2007). Role of androgens in fetal testis development and dysgenesis. Endocrinology 148, 2027-2036. doi: 10.1210/en.2006-1622

Scott, H. M., Mason, J. I., and Sharpe, R. M. (2009). Steroidogenesis in the fetal testis and its susceptibility to disruption by exogenous compounds. Endocr. Rev. 30, 883-925. doi: 10.1210/er.2009-0016

Sever, L. E., Arbuckle, T. E., and Sweeney, A. (1997). Reproductive and developmental effects of occupational pesticide exposure: the epidemiologic evidence. Occup. Med. 12, 305-325.

Sharpe, R. M. (2001). Hormones and testis development and the possible adverse effects of environmental chemicals. Toxicol. Lett. 120, 221-232. doi: 10.1016/S0378-4274(01)00298-3
Sharpe, R. M., McKinnell, C., Kivlin, C., and Fisher, J. S. (2003). Proliferation and functional maturation of Sertoli cells and their relevance to disorders of testis function in adulthood. Reprodution 125, 769-784. doi: 10.1530/rep.0. 1250769

Shaw, I., and McCully, S. (2002). A review of the potential impact of dietary endocrine disrupters on the consumer. Int. J. Food Sci. Technol. 37, 471-476 doi: 10.1046/j.1365-2621.2002.00595.x

Shi, Z., Valdez, K. E., Ting, A. Y., Franczak, A., Gum, S. L., and Petroff, B. K. (2007). Ovarian endocrine disruption underlies premature reproductive senescence following environmentally relevant chronic exposure to the aryl hydrocarbon receptor agonist 2,3,7,8-tetrachlorodibenzo-pdioxin. Biol. Reprod. 76, 198-202. doi: 10.1095/biolreprod.106.053991

Si, J., Li, P., Xin, Q., Li, X., An, L., and Li, J. (2015). Perinatal exposure to low doses of tributyltin chloride reduces sperm count and quality in mice. Environ. Toxicol. 30, 44-52. doi: 10.1002/tox.21892

Silva, M. J., Reidy, J. A., Herbert, A. R., Preau Jr. J. L., Needham, L. L., and Calafat, A. M. (2004). Detection of phthalate metabolites in human amniotic fluid. Bull. Environ. Contam. Toxicol. 72, 1226-1231. doi: 10.1007/s00128-004-0374-4

Silva, M. J., Reidy, J. A., Samandar, E., Herbert, A. R., Needham, L. L., and Calafat, A. M. (2005). Detection of phthalate metabolites in human saliva. Arch. Toxicol. 79, 647-652. doi: 10.1007/s00204-005-0674-4

Skinner, M. K. (2011). Role of epigenetics in developmental biology and transgenerational inheritance. Birth Defects Res. C Embryo Today 93, 51-55. doi: 10.1002/bdrc.20199

Soares, A., Guieysse, B., Jefferson, B., Cartmell, E., and Lester, J. N. (2008). Nonylphenol in the environment: a critical review on occurrence, fate, toxicity and treatment in wastewaters. Environ. Int. 34, 1033-1049. doi: 10.1016/j.envint.2008.01.004

Soto, A. M., Justicia, H., Wray, J. W., and Sonnenschein, C. (1991). p-Nonyl-phenol: an estrogenic xenobiotic released from modified polystyrene. Environ. Health Perspect. 92, 167-173. doi: 10.1289/ehp.9192167

Soto, A. M., and Sonnenschein, C. (2010). Environmental causes of cancer: endocrine disruptors as carcinogens. Nat. Rev. Endocrinol. 6, 363-370. doi: 10.1038/nrendo. 2010.87

Srivastava, S., Singh, G. B., Srivastava, S. P., and Seth, P. K. (1990). Testicular toxicity of di-n-butyl phthalate in adult rats: effect on marker enzymes of spermatogenesis. Indian J. Exp. Biol. 28, 67-70.

Stillman, R. J. (1982). In utero exposure to diethylstilbestrol: adverse effects om the reproductive tract and reproductive performance and male and female offspring. Am. J. Obstet. Gynecol. 142, 905-921.

Stoker, T. E., Cooper, R. L., Lambright, C. S., Wilson, V. S., Furr, J., and Gray, L. E. (2005). In vivo and in vitro antiandrogenic effects of DE-71, a commercial polybrominated diphenyl ether (PBDE) mixture. Toxicol. Appl. Pharmacol. 207, 78-88. doi: 10.1016/j.taap.2005.05.010

Stroheker, T., Cabaton, N., Nourdin, G., Régnier, J. F., Lhuguenot, J. C., and Chagnon, M. C. (2005). Evaluation of anti-androgenic activity of di-(2ethylhexyl) phthalate. Toxicology 208, 115-121. doi: 10.1016/j.tox.2004.11.013

Su, P. H., Chang, Y. Z., Chang, H. P., Wang, S. L., Haung, H. I., Huang, P. C., et al. (2012). Exposure to di(2-ethylhexyl) phthalate in premature neonates in a neonatal intensive care unit in Taiwan. Pediatr. Crit. Care Med. 13, 671-677. doi: 10.1097/PCC.0b013e3182455558

Suzuki, Y., Yoshinaga, J., Mizumoto, Y., Serizawa, S., and Shiraishi, H. (2011). Foetal exposure to phthalate esters and anogenital distance in male newborns. Int. J. Androl. 35, 236-244. doi: 10.1111/j.1365-2605.2011.01190.x

Svechnikov, K., Izzo, G., Landreh, L., Weisser, J., and Soder, O. (2010). Endocrine disruptors and Leydig cell function. J. Biomed. Biotechnol. 2010:684504. doi: $10.1155 / 2010 / 684504$

Svechnikov, K., Stukenborg, J.-B., Savchuck, I., and Soder, O. (2014). Similar causes of various reproductive disorders in early life. Asian J. Androl. 16, 50-59. doi: 10.4103/1008-682X.122199

Swan, S. H., Main, K. M., Liu, F., Stewart, S. L., Kruse, R. L., Calafat, A. M., et al. (2005). Decrease in anogenital distance among male infants with prenatal phthalate exposure. Environ. Health Perspect. 113, 1056-1061. doi: 10.1289/ehp. 8100

Takao, T., Nanamiya, W., Nazarloo, H. P., Matsumoto, R., Asaba, K., and Hashimoto, K. (2003). Exposure to the environmental estrogen bisphenol A differentially modulated estrogen receptor-alpha and -beta immunoreactivity and mRNA in male mouse testis. Life Sci. 72, 1159-1169. doi: 10.1016/S00243205(02)02364-0 
Thomas, J. A., and Thomas, M. J. (1984). Biological effects of di-(2-ethylhexyl) phthalate and other phthalic acid esters. Crit. Rev. Toxicol. 13, 283-317. doi: 10.3109/10408448409023761

Thompson, C. J., Ross, S. M., and Gaido, K. W. (2004). Di(n-butyl) phthalate impairs cholesterol transport and steroidogenesis in the fetal rat testis through a rapid and reversible mechanism. Endocrinology 145, 1227-1237. doi: 10.1210/en.2003-1475

Thompson, C. J., Ross, S. M., Hensley, J., Liu, K., Heinze, S. C., Young, S. S., et al. (2005). Differential steroidogenic gene expression in the fetal adrenal gland versus the testis and rapid and dynamic response of the fetal testis to di(n-butyl) phthalate. Biol. Reprod. 73, 908-917. doi: 10.1095/biolreprod.105.042382

Tiemann, U. (2008). In vivo and in vitro effects of the organochlorine pesticides DDT, TCPM, methoxychlor, and lindane on the female reproductive tract of mammals: a review. Reprod. Toxicol. 25, 316-326. doi: 10.1016/j.reprotox.2008.03.002

Timms, B. G., Howdeshell, K. L., Barton, L., Bradley, S., Richter, C. A., and vom Saal, F. S. (2005). Estrogenic chemicals in plastic and oral contraceptives disrupt development of the fetal mouse prostate and urethra. Proc. Natl. Acad. Sci. U.S.A. 102, 7014-7019. doi: 10.1073/pnas.0502544102

Toyama, Y., and Yuasa, S. (2004). Effects of neonatal administration of $17 \mathrm{~b}-$ estradiol, b-estradiol 3-benzoate, or bisphenol A on mouse and rat spermatogenesis. Reprod. Toxicol. 19, 181-188. doi: 10.1016/j.reprotox.2004.08.003

Tubau, I., Vázquez-Suñé, E., Carrera, J., González, S., Petrovic, M., López de Alda, M. J., et al. (2010). Occurrence and fate of alkylphenol polyethoxylate degradation products and linear alkylbenzene sulfonate surfactants in urban ground water: Barcelona case study. J. Hydrol. 383, 102-110. doi: 10.1016/j.jhydrol.2009.11.030

Vandenberg, L. N., Chahoud, I., Heindel, J. J., Padmanabhan, V., Paumgartten, F. J., and Schoenfelder, G. (2010). Urinary, circulating, and tissue biomonitoring studies indicate widespread exposure to bisphenol A. Environ. Health Perspect. 118, 1055-1070. doi: 10.1289/ehp.0901716

Vega, A., Baptissart, M., Caira, F., Brugnon, F., Lobaccaro, J. M., and Volle, D. H. (2012). Epigenetic: a molecular link between testicular cancer and environmental exposures. Front. Endocrinol. 3:150. doi: 10.3389/fendo.2012.00150

Vinas, R., and Watson, C. S. (2013). Bisphenol S disrupts estradiol-induced nongenomic signaling in a rat pituitary cell line: effects on cell functions. Environ. Health Perspect. 121, 352-358. doi: 10.1289/ehp.1205826

Vrijiheid, M., Armstrong, B., Dolk, H., van Tongeren, M., and Botting, B. (2003). Risk of hypospadias in relation to maternal occupational exposure to potential endocrine disrupting chemicals. Occup. Environ. Med. 60, 543-550. doi: 10.1136/oem.60.8.543

vom Saal, F. S., Cooke, P. S., Buchanan, D. L., Palanza, P., Thayer, K. A., Nagel, S. C., et al. (1998). A physiologically based approach to the study of bisphenol A and other estrogenic chemicals on the size of reproductive organs, daily sperm production, and behavior. Toxicol. Ind. Health 14, 239-260. doi: 10.1177/074823379801400115

Wang, Y., Song, L., Hong, X., Cui, L., Zhang, Z., Xiao, H., et al. (2006). Low concentrations mono-butyl phthalate stimulates steroidogenesis by facilitating steroidogenic acute regulatory protein expression in mouse Leydig tumor cells (MLTC-1). Chem. Biol. Interact. 164, 15-24. doi: 10.1016/j.cbi.2006.08.022

Wang, Y. B., Song, L., Cui, L. B., Hong, X., Zhang, Z. D., and Wang, X. R. (2007). Monobutyl phthalate inhibits steroidogenesis by downregulating steroidogenic acute regulatory protein expression in mouse Leydig tumor cells (MLTC-1). J. Toxicol. Environ. Health A 70, 947-955. doi: 10.1080/15287390701290717

Wang, H., Wang, S. F., Ning, H., Ji, Y. L., Zhang, C., Zhang, Y., et al. (2011). Maternal cypermethrin exposure during lactation impairs testicular development and spermatogenesis in male mouse offspring. Environ. Toxicol. 26, 382-394. doi: 10.1002/tox.20566
Welsh, M., Sauders, P. T., Fisken, M., Scott, H. M., Hutchinson, G. R., Smith, L. B., et al. (2008). Identification in rats of a programming window for reproductive tract masculinization, disruption of which leads to hypospadias and cryptorchidism. J. Clin. Invest. 118, 1479-1490. doi: 10.1172/ JCI34241

Williams, K., McKinnell, C., Saunders, P. T., Walker, M., Fisher, J. S., Turner, K. J., et al. (2001). Neonatal exposure to potent and environmental oestrogens and abnormalities of the male reproductive system in the rat: evidence for importance of the androgen-oestrogen balance and assessment of the relevance to man. Hum. Reprod. Update 7, 236-247. doi: 10.1093/humupd/ 7.3.236

Williams, K., McKinnell, C., Saunders, P., Walker, M., Fisher, J., Turner, K., et al. (2011). Neonatal exposure to potent and environmental oestrogens and abnormalities of the male reproductive system in the rat: evidence for importance of the androgen-oestrogen balance and assessment of the relevance to man. APMIS 109, S493-S504. doi: 10.1111/j.1600-0463.2001. tb05805.x

Wilson, J. D. (1978). Sexual differentiation. Annu. Rev. Physiol. 40, 279-306. doi: 10.1146/annurev.ph.40.030178.001431

Wittassek, M., Koch, H. M., Angerer, J., and Brüning, T. (2011). Assessing exposure to phthalates - the human biomonitoring approach. Mol. Nutr. Food Res. 55, 7-31. doi: 10.1002/mnfr.201000121

Woodruff, T. J. (2011). Bridging epidemiology and model organisms to increase understanding of endocrine disrupting chemicals and human health effects. J. Steroid Biochem. Mol. Biol. 127, 108-117. doi: 10.1016/j.jsbmb.2010. 11.007

Yu, M., Wang, J., Liu, W., Qin, J., Zhou, Q., Wang, Y., et al. (2014). Effects of tamoxifen on the sex determination gene and the activation of sex reversal in the developing gonad of mice. Toxicology 321, 89-95. doi: 10.1016/j.tox.2014. 04.006

Zhang, Q., Bai, Q., Yuan, Y., Liu, P., and Qiao, J. (2010). Assessment of seminal estradiol and testosterone levels as predictors of human spermatogenesis. J. Androl. 31, 215. doi: 10.2164/jandrol.109.007609

Zhang, L., Dong, L., Ding, S., Qiao, P., Wang, C., Zhang, M., et al. (2014). Effects of $n$-butylparaben on steroidogenesis and spermatogenesis through changed $\mathrm{E}_{2}$ levels in male rat offspring. Environ. Toxicol. Pharmacol. 37, 705-717. doi: 10.1016/j.etap.2014.01.016

Zhao, Y., and Hu, J. (2012). Development of a molecular biomarker for detecting inter-sex after exposure of male medaka fish to synthetic estrogen. Environ. Toxicol. Chem. 31, 1765-1773. doi: 10.1002/etc.1892

Conflict of Interest Statement: The authors declare that the research was conducted in the absence of any commercial or financial relationships that could be construed as a potential conflict of interest.

Received: 29 November 2014; accepted: 14 January 2015; published online: 17 February 2015.

Citation: De Falco M, Forte $M$ and Laforgia V (2015) Estrogenic and anti-androgenic endocrine disrupting chemicals and their impact on the male reproductive system. Front. Environ. Sci. 3:3. doi: 10.3389/fenvs.2015.00003

This article was submitted to Environmental Toxicology, a section of the journal Frontiers in Environmental Science.

Copyright (C) 2015 De Falco, Forte and Laforgia. This is an open-access article distributed under the terms of the Creative Commons Attribution License (CC BY). The use, distribution or reproduction in other forums is permitted, provided the original author(s) or licensor are credited and that the original publication in this journal is cited, in accordance with accepted academic practice. No use, distribution or reproduction is permitted which does not comply with these terms. 